\title{
Diversity of the Local Varieties from grapevine Tree in the Northwestern of Morocco
}

\author{
El Oualkadi A*, Hajjaj B*
}

*INRA- Regional Agricultural Research Center of Tangier, Morocco

Corresponding author. E-mail: ai.oualkadi@gmail.com

\begin{abstract}
The culture of grapevine in Morocco is ancestral and preserves a particular importance in the traditional agroecosystems of the Riffian mountains. But the importance of varietal diversity remains ignored. These study was carried out to evaluate this diversity, for that a investigations and investigations were carried out in north-west of the country. The stations were selected according to the importance of the orchards of grapevine tree in the agroecosystem. A complete description morphological, physiological and pomological relating the tree and the fruit was carried out. The culture of grapevine in the area of study show a great diversity with 21 listed native varieties. One notes a great confusion of denomination on the level of the prospected varieties. This problem can be with several causes and mainly with the errors of appreciation of the characters or the differences of local names which vary from one locality to another.
\end{abstract}

Keywords-Grapevine, varietal diversity, traditional agroecosystem, Morocco.

\section{INTRODUCTION}

Vitis vinifera $L$., the commonly cultivated grapevine, is one of the most widely grown fruit plants in the world [1]. The cultivated grape $V$. vinifera subsp. sativa has played an important economic and cultural role throughout human history in different parts of the world. However, its ancestor the European wild grape V. vinifera subsp. sylvestris, is close to extinction. In Morocco, the grapevine as well as the olive tree, the fig tree and the cereals are cultures well adapted to the natural climatic conditions of our country located at the end of the western Mediterranean. The culture of the grapevine is practiced in a traditional way. It uses a vegetable material not selected based on local varieties with localized denomination and distribution. This culture remains especially in the traditional agroecosystem like the agroecosystem of mountains. It is the case of the Riffian mountains in the areas north of Morocco where this 90-93\% national orchard concentrate. These agroecosystem was characterized valence of the micro property $(<0.5$ ha) and small property ( $<5 \mathrm{ha}$ ) and a weak useful agricultural area [2], [3]. The Riffian field is very heterogeneous (climate, ground, relief, occupation of the ground), and the diversity is much contrasted nature sometimes of the agroecosystems of this area [4]. Arboriculture like grapevine and fig is one of the principal productions in these agroecosystems. The culture of grapevine is in clear regression, historically it's occupied a dominating place, the grapevine fruit and dried grapes were exchanged against cereals coming from the plains. Many ampelographic studies have been made of grapevine cultivars from all over the world, but only a few have described those of Algeria and Morocco [5], [6], [7], [8]. Recently, many of the Maghreb cultivars have now been profiled by nuclear and chloroplast microsatellite analysis [9], [10], [11], [12], [13]. Grapevine varieties have been characterized for identification purposes by ampelographic characters [14], [15], [16]. Study of plant morphology, mainly leaves, buds, and cluster morphology (also called ampelography) until it is the last means of detecting vine cultivars [17]. This method is still used for identification [18], [19], [20] particularly during the collection of data plants in situ. Into this article, one proposes to present some aspects of the culture of the grapevine in the mountains agroecosystem and show the importance of varietal diversity in these areas.

\section{MATERIAL AND METHODS}

Work was based on prospecting and investigations carried out in 3 stations in Northwestern of the country. These stations were selected according to the importance of the orchards of the grapevine tree in the agroecosystem. The orchards where the samples were collected were localized using a GPS (Table.1). The investigations are based on the use of a questionnaire bearing into socio-economic and agronomic aspects of the culture of the grapevine. During the prospecting a complete description of the varieties was assured, relating the tree and the fruit. The descriptors used were adapted list drawn up OIV descriptors of the OIV (International Office of Vine and Wine) and phenological 
stages of [21]. The evaluation of the plant health state of the trees related to the diseases whose symptoms are clearly defined and who are easily observable in situ on the tree. The data processing was carried out by using the NTSYSpc software for the analyses of similarities and algorithm UPGMA for the construction of the clusters.

Table 1: Location of prospecting sites

\begin{tabular}{lcl}
\hline Locality & Altitude & Geographic coordinate \\
\hline \multirow{2}{*}{ BNI HAMDILLAH } & \multirow{2}{*}{$303 \mathrm{~m}$} & $\begin{array}{l}35^{\circ} \mathrm{N}-02,009^{\prime} \\
0,5^{\circ} \mathrm{W} 19,870^{\prime}\end{array}$ \\
& & $35^{\circ} \mathrm{N}-54,627^{\prime}$ \\
MOKRISSAT & $562 \mathrm{~m}$ & $0,05^{\circ} \mathrm{W}-20,687^{\prime}$ \\
& & $34^{\circ} \mathrm{N}-49,690^{\prime}$ \\
ZOUMI & $648 \mathrm{~m}$ & $0,5^{\circ} \mathrm{W}-16,783^{\prime}$ \\
& & $35^{\circ} \mathrm{N}-12,3377^{\prime}$ \\
& $359 \mathrm{~m}$ & $0,05^{\circ} \mathrm{W}-19,568^{\prime}$ \\
\hline
\end{tabular}

\section{RESULTS AND DISCUSSIONS}

\section{Socioeconomics Aspects}

Most of the orchard owners $(80 \%)$ have found that vine growing is just additional activity for which they hold hardly the $1 / 10$ of the cultivated surface. Often the orchard is for subsistence farming. We note the regression of orchards that are abandoned in favor of other crops considered more profitable, this also due to the lack of commercial sector infrastructure. Most of the production is consumed on site or transformed into traditional grape juice called Samet.

\section{Agronomic Aspects and Plant Health State}

According to the investigations carried out at the vineyards traditional, the farmers affirm that the vine is well adapted on the climatic ground and conditions and it does not require any particular care. The Scandinavian Western exposure and of north however are preferred because they offer a certain freshness which compensates for the poverty of the ground. Cultivating techniques like cutting, the agricultural work, the fertilization or pollination are seldom practiced. The lack of care leads to an exaggerated development of the tree which supports the development of the diseases. The study of health of factory proves that the majority of the orchards are touched by the various diseases of which most frequent are gray rot and the mildew. However, the farmers affirm that in the majority of the cases which the diseases do not affect the productivity of the trees.

\section{Varietal Diversity and Richness of Local Varieties}

The prospection carried out in the area assures us the seniority of the varieties. The farmers affirm that the majority of the vines are local and very few varieties were introduced and confirm the nature of the vegetable material of the local varieties. The prospection showed a great morphological diversity, thus we counted not less than 21 local varieties or denominations (Table.2).

Among the listed varieties, it is Taferylat which is drawn aside and more appreciated. We finds denominations identified in other sectors of region, like Dibi, Boukhanzir, Ineb Byad, Bezoul awda, Sbiyae bnate, Mouksa bayda and mouska hamra. But, ther are also varieities as for example whose names are quoted for the first time, Sans, Zbarjel, Maticha Ineb nhal...

The variety Dibi showed the higher weight of grappe $(872 \mathrm{~g})$, the low value was observed in the variety Mouska hamra $(20 \mathrm{~g})$. The most sweet fruit was Taferylat bayd with the maximum value of brix (49), but the acidic fruit was Feryal khal with the minimum value of brix (29) (Table.1).

Table.1. Principal Characteristics of local varieties listed in this study.

\begin{tabular}{lcclll}
\hline Variety & Weight grappe $(\mathrm{g})$ & Brix & Compactness & Shape of the fruit & Color of the epidermis \\
\hline Feryal Khal1 & 435 & 29 & Medium & Ovoid & Red purple \\
Taferyalt kahla8 & 296 & 46 & Compact & Flattened at the ends & Pink \\
Aferyal Byad1 & 551 & 42 & Medium & Elliptical & Green yellow \\
Taferyalt Byad3 & 74 & 49 & Loose & Rounded & Pink \\
Dibi 1 & 872 & 45 & Loose & Flattened at the ends & Pink \\
Echabel(Dibi) & 348 & 37 & Very loose & Rounded & Pink \\
Dibani 1 & 359 & 35 & Loose & Rounded & Green yellow \\
Maticha Mferqa & 71 & 47 & Loose & Flattened at the ends & Red purple \\
Maticha Mjemaa & 138 & 40 & Compact & Flattened at the ends & Green yellow \\
Mouska Bayda & 184 & 38 & Medium & Troncovoid & Pink \\
Mouska hamra1 & 20 & 46 & Very loose & Elliptical & Pink \\
Ineb Nhal & 263 & 35 & Compact & Rounded & Dark blue \\
Fekas khal & 445 & 32 & Compact & Rounded & Red purple \\
Fekas Byad & 222 & 37 & Very compact & Obovoid & Pink \\
Ineb Byad1 & 367 & 35 & Medium & Rounded & Green yellow
\end{tabular}




\begin{tabular}{lcclll} 
Bezoul awda 1 & 43 & 40 & Very loose & Ovoid & Green yellow \\
Boukhanzir1 & 352 & 42 & Very compact & Rounded & Red \\
Sbiyae Bnat & 93 & 39 & Compact & Rounded & Green yellow \\
Rjiyil Dib 1 & 277 & 55 & Medium & Troncovoid & Red purple \\
Zbarjel & 90 & 35 & Compact & Rounded & Red purple \\
Sanso & 251,28 & 40 & Compact & Flattened at the ends & Red purple \\
\hline
\end{tabular}

By the use the ampelometric data we realized a hierarchical classification (Fig.2). This classification is based on distances measured by a similarity index. This analysis consists of gradually aggregating the individuals according to their similarity. The hierarchical ascending classification requires the definition of a measure of similarity (distance) or a criterion of aggregation of objects (samples). According to [22] she produces a suite of nested partitions of the set of objects to classify. In our study, this analysis was carried out by introducing the mean values of each variable for each tree.

The analysis of the dendrogram of the hierarchical classification (Fig. 1) shows the existence of two main groups (classes) divided in turn into several subgroups. The first class has 12 trees: it can be subdivided into two subclasses, Subclass 1 with Taferyalt Byad2 and Maticha Mferqa. Subclass 2 with Bezoul El awda1, Mouska, Taferyalt Kahla5, Sanso, Fekas Byad, Ineb Nhal, Ineb Byad2, Maticha Mjemaa, Ineb Byad1 and Fekas Khal. We notice the strongest similarity is observed in Fekas Byad and Sanso. The second class has 27 trees. The Subclass 1 represented by the single tree: Zbarjel distinguished mainly from other tree studied.

Subclass 2 with Fekass, Boukhanzur1, Taferyalt Kahla8, Taferyalt Kahla6, Rjiyil Dib2, Rjiyil Dib1 and Taferyalt Kahla .Mouska Hamra2 and Sbiyae El bnat. Boukhanzir3, Dibani2, Taferyalt Kahla2, Taferyalt Byad4, Taferyalt Byad3, Taferyalt Khal4, Boukhanzir2. Mouska Bayda,
Dibani1, Dibi2, Mouska Hamra1, Dibi1, Dibi3, Taferyalt Kahla3, Taferyalt Byad1 and Taferyalt Khal1.

In this group the tree with the strongest similarity are Taferyalt Khal7 and Rjiyil Dib1, Taferyalt Byad3 and Taferyalt Byad4, Taferyalt Kahla4 and Boukhanzir2, Dibi2 and Dibani1, Taferyalt Khal1 and Taferyalt Byad1.

The varieties which bear the same name have fruits with similar pomological characters, but it is far from being a general case. Indeed, of the notable differences can be observed within the same variety so much so that individuals supposed to belong to the same variety can be different and separate on the analysis (Fig. 1).

We think that they can be in certain cases different varieties but bearing the same name (homonymy) or on the contrary same varieties but carrying different local names (synonymy).

It is thus necessary to record the importance of the problems of denomination of the varieties listed in the prospected area. These problems are due to local names which sometimes vary from one locality to another and the absence of the syntheses and varietal characterization. 


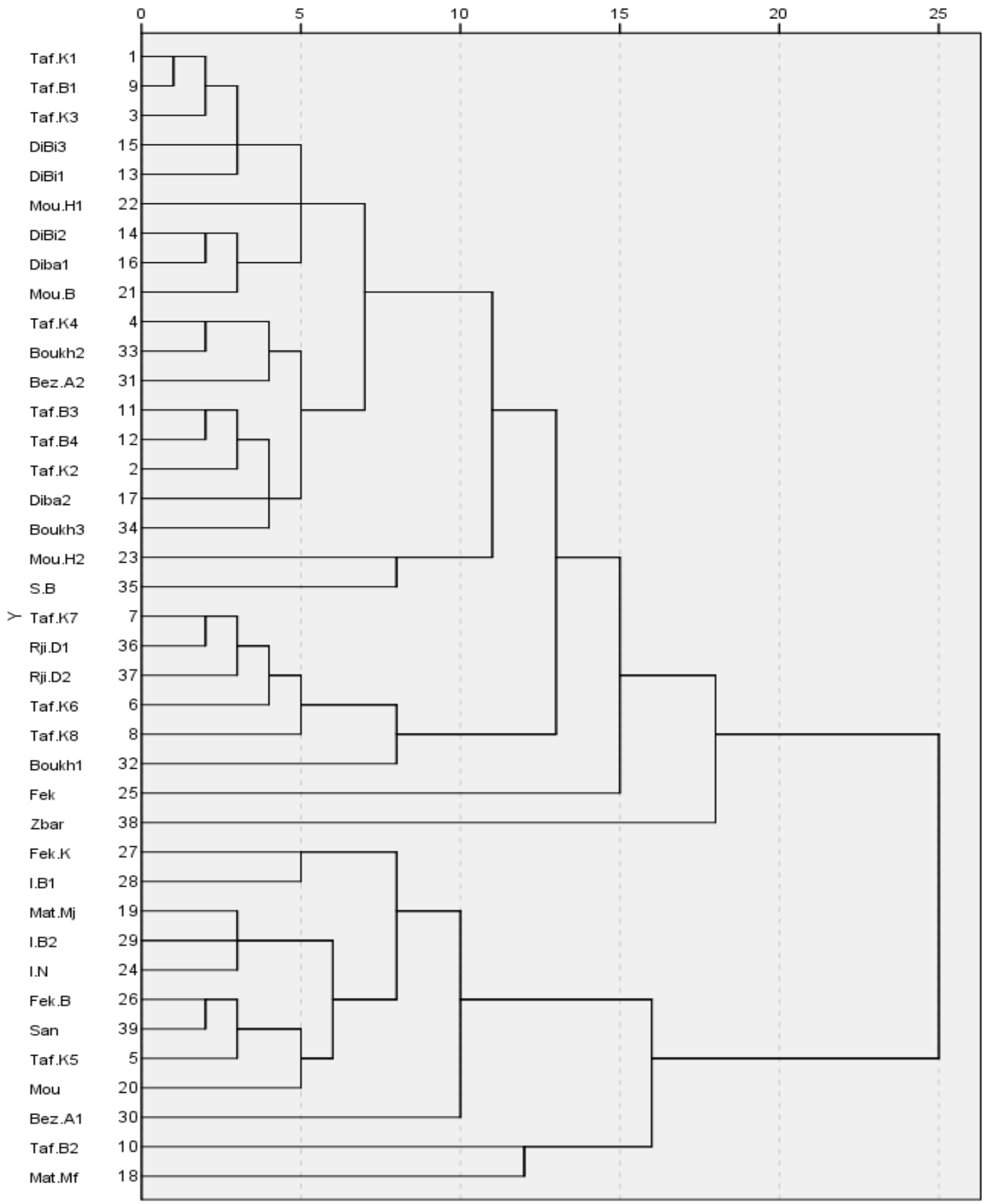

Fig. 1. Representation in cluster of individuals of the north region of Morocco.

\section{CONCLUSION}

The culture of the grapevine in the north Morocco is practiced in a traditional way. The vegetable material used corresponds to very old varieties or local denominations. There are no introductions or uses of new or selected varieties. Although the prospecting was made on a limited study they showed the existence of a great varietal diversity. Indeed, Twenty one "local varieties" were listed in this study. However, in the absence of a pomological and morphological characterization, the value of the varietal denominations poses problems. One is in the presence of an important genetic inheritance little known who the evaluation is and the characterization is not carried out yet. The regression of this culture and the transformations socio-economic that the area knows constitute a serious threat of erosion and of loss of this phytogenetic resource. 


\section{ACKNOWLEDGEMENTS}

The authors are grateful to all farmers for providing necessary facilities for conducting this research work.

\section{REFERENCES}

[1] Vivier MA, Pretorius IS (2002) Genetically tailored grapevines for the wine industry. Trends Biotechnol.20:472-8.

[2] Chaara, A (1996) L'agriculture et la pêche dans le littoral du Rif. Ed. Association Tétouan Asmir. Tétouan.

[3] Bajeddi, M (2001) Revenu et viabilité des exploitations en agriculture pluviale au Maroc. Salma Impression. Rabat. Maroc.

[4] El Gharbaoui, A (1980) La terre et l'homme dans la péninsule Tingitane: étude sur l'homme et le milieu naturel dans le Rif occidental. Thèse d'Etat. Université Paris.

[5] Föex, G. (1891) Cours complet de viticulture (Georges Masson LibraireÉditeur: Paris, France).

[6] Isnard, H (1951) La vigne en Algérie. Etude geographique (Ophrys: Gap, France).

[7] Vidal, J.P (1951) La vigne au Maroc (Terre Marocaine: Casablanca, Morocco)

[8] Levadoux, L., Benabderrabou, A. and Douaouri, B (1971) Ampélographie Algérienne: Cépages de cuve et de table cultivés en Algérie (SNED: Alger, Algeria).

[9] El Oualkadi, A., Ater, M., Messaoudi, Z., Laucou, V., Boursiquot, J.M., Lacombe, T. and This, P (2009) Molecular characterization of Moroccan grapevine germplasm using SSR markers for the establishment of a reference collection. Journal International des Sciences de la Vigne et du Vin 43, 135-148.

[10] El Oualkadi, A., Ater, M., Messaoudi, Z., El Heit, K., Laucou, V., Boursiquot, J.M., Lacombe, T. and This, P (2011) Genetic diversity of Moroccan grape accessions conserved ex situ compared to Maghreb and European gene pools. Tree Genetics \& Genomes 7, 1287-1298.

[11] Laiadi, Z., Bentchikou, M.M., Bravo, G., Cabello, F. and Martinez-Zapater, J.M. (2009) Molecular identification and genetic relationships of Algerian grapevine cultivars maintained at the germplasm collection of Skikda (Algeria). Vitis 48, 25-32.

[12] Riahi, L., Zoghlami, N., El-Heit, K., Laucou, V., Le Cunff, L., Boursiquot, J.M., Lacombe, T., Mliki, A., Ghorbel, A. and This, P (2010) Genetic structure and differentiation among grapevines (Vitis vinifera) accessions from Maghreb region. Genetic Resources and Crop Evolution 57, 255272.

[13] Zinelabidine, L.H., Haddioui, A., Bravo, G., ArroyoGarcia, R. and Zapater, J.M.M. (2010) Genetic origins of cultivated and wild grapevines from Morocco. American Journal of Enology and Viticulture 61, 83-90

[14] Clemente, S. de R (1807) Ensayo sobre las variedades de vid común que vegetan en Andalucia, Madrid.

[15] Viala, P. \& V. Vermorel (1905) Ampélographie. Imp. Masson et Cie, Paris.
[16] Galet, P (1962) Cépages et vignobles de France. Tome III, Les cépages de cuve (2a partie). Imp. Le Paysan du Midi. Montpellier.

[17] Boursiquot JM, This P (1996) Les nouvelles techniques utilisées en ampélographie: Informatique et marquage. J Int Sci Vigne Vin Special issue: 12-23.

[18] Arrigo N. \& Arnold C (2007) Naturalised Vitis rootstocks in Europe and consequences to native wild grapevine. PlosOne 6, 521.

[19] Ortiz JM, Martin JP, Borrego J (2004) Molecular and morphological characterization of a Vitis gene bank for the establishment of a base collection. Genetic Resources and Crop Evolution 51: 403-409.

[20] Pavek DS, Lamboy WF et Garvey EJ (2003) Selecting in situ conservation sites for grape genetic resources in the USA. Genetics Ressources and Crop Evolution 50: 165173.

[21] Baggiolini M (1952) Les stades repères dans le développement annuel de la vigne et leur utilisation pratique. Revue romande d'Agriculture et d'Arboriculture 8 (1), 4-6.

[22] Duchez and Loy (2005) Organisation des Nations Unies par l'horticulture et l'Alimentation Rome. 